\title{
ORDER OF POST-ADJUNCTS TO NOUNS IN DUTCH
}

\section{INTRODUCTION}

In 1956 my article on "Kategorieën van voorgeplaatste bepalingen" (Categories of pre-adjuncts to nouns) was published in Levende Talen pp. $474 \mathrm{ff}$. It was corrected and supplemented by others, e.g. H. F. A. van der Lubbe in his "Woordvolgorde in het Nederlands" (Word-order in Dutch), pp. 112ff. As the subject under consideration is the counterpart of that article, a brief summary of it may be welcome.

I started from the rather artificial construction:

mijn lalrijke tweede drie mooie kleine rode houter kistjes,

$\begin{array}{lllllllll}8 & 7 & 6 & 5 & 4 & 3 & 2 & 1 & 0\end{array}$

(my numerous second three beautiful small red wooden boxes) in which the order of succession of the pre-adjuncts cannot be altered. "his order appears to be based on an srder of inherence of the quality rneant in the pre-adjunct to the thing denoted in the noun. The more inherent the quality denoted, the closer the pre-adjunct stands to the noun. I established the degree of inherence by investigating the possible burden of each pre-adjunct in distinctive function: which in its turn was established on the basis of the extent of the alteration of the thing meant, necessary to use correctly a pre-adjunct of some class instead of another of the same class: e.g. the alteration of the thing meant in iron boxes necessary to denote them correctly with wooden boxes, is more extensive than the one of the thing meant in blue boxes, needed to denote them correctly with red boxes. So preadjuncts of the wooden-iron-class denote: qualities more inherent to the thing meant in the head-word than those of the blue-red-class; consequent'y they stand closer to the noun. In this way I arrived at a conclusion which can be summarized in the table on next page.

in his thesis, "Vergelijkende studie van de structuur der substantiefgroepen in het Engels en het Nederlands" (Leuven 1959) (Comparative Study of the Structure of Noun-constructions in English and Dutch) J. van Roey compared my results to those found by $C$. W. Barritt: "The Order-classes of Modifiers in English" (unpublished 
Order of pre-adjuncts to nouns in Dutch

\begin{tabular}{|c|c|c|c|c|c|c|c|c|}
\hline deictic & \multicolumn{8}{|c|}{ non-deictic } \\
\hline & \multicolumn{3}{|c|}{ quantitative } & \multicolumn{4}{|c|}{ qualitative } & \\
\hline & relative & non-re & lative & $\begin{array}{l}\text { sub- } \\
\text { jective }\end{array}$ & \multicolumn{3}{|c|}{ non-subjective } & \\
\hline & & \multirow{2}{*}{ ordinal } & $\begin{array}{c}\text { non- } \\
\text { ordinal }\end{array}$ & \multirow[b]{3}{*}{$\begin{array}{c}\text { 4th } \\
\text { place } \\
\text { mooie } \\
\text { beauti- } \\
\text { ful }\end{array}$} & relative & \multicolumn{2}{|c|}{ non-relative } & \\
\hline & & & & & & $\begin{array}{l}\text { objec- } \\
\text { tive }\end{array}$ & $\begin{array}{l}\text { non-ob- } \\
\text { jective }\end{array}$ & \\
\hline $\begin{array}{l}\text { 8th } \\
\text { place } \\
\text { mijn } \\
\text { my }\end{array}$ & $\begin{array}{c}\text { 7th } \\
\text { place } \\
\text { talrijke } \\
\text { numer- } \\
\text { ous }\end{array}$ & $\begin{array}{c}\text { 6th } \\
\text { place } \\
\text { tweede } \\
\text { second }\end{array}$ & $\begin{array}{l}\text { 5th } \\
\text { place } \\
\text { drie } \\
\text { three }\end{array}$ & & $\begin{array}{c}\text { 3d } \\
\text { place } \\
\text { kleine } \\
\text { small }\end{array}$ & $\begin{array}{l}\text { 2nd } \\
\text { place } \\
\text { rode } \\
\text { red }\end{array}$ & $\begin{array}{c}\text { 1st } \\
\text { place } \\
\text { houten } \\
\text { wooden }\end{array}$ & $\begin{array}{l}\text { kistjes } \\
\text { boxes }\end{array}$ \\
\hline
\end{tabular}

thesis, University of Virginia, 1952) and by A. A. Hill: "Introduction to Linguistic Structures. From Sound to Sentence in English" (New York 1958).

We hardly flatter ourselves with the hope of having collected all existing types of post-adjuncts ${ }^{1}$ ) in:

die kistjes sigaren van hout doar die besteid waren wankelen $\begin{array}{llllll}0 & 1 & 2 & 3 & 4 & 5\end{array}$

[those boxes (of) cigars (made) of wood (over) there (that had been) ordered (are) totter(ing); we shall try in each case to translate Dutch constructions into English with preservation of peculiarities of Dutch syntax, at the risk of deviating from English syntactic structure here and there].

This uncertainty is not so bad as it seems: if we have used the correct order of succession here and we discover a semantic order corresponding with it (cf. note 1 at the end of this article), it will not be difficult to incorporate possible new types of adjuncts on the basis of their semantic qualities.

1) The word adjunct is used here in the sense of: word or construction forming a new non-coordinate construction with another word or construction; so without expressing an opinion whether the resulting construction is endo- or exocentric. Which member, in the former case, is determinans and which determinatum, is also left undecided. 
There will not be much doubt that we have used the correct order of succession here. The place of e.g. sigaren and wankelen will not be contested; neither will it be contradicted that van hout and die besteld waren are not interchangeable. We are not so sure of the place of daar: an order of succession de kistjes die besteld waren daar, or rather, to prevent all ambiguity (The boxes over there? or ordered there?), de kistjes die leeg waren daar (the boxes that were empty over there) cannot be regarded as a priori impossible. However, this uncertainty is not so alarming either: if we consider the place of this adjunct as hypothetical, there is nothing to prevent us from adapting our hypothesis afterwards. But as we shall see, this will not be necessary: the doubt is only caused by the rare use of a construction with adjuncts 3 and 4 together.

In order to discover a semantic hierarchy in these post-adjuncts now, re must first establish what is proper to all of them; in other words ' what in fact is a post-adjunct? The obvious way to answer this question is to compare the post-adjuncts with the pre-adjuncts. Therefore we shall try each time tu compare pre- and post-adjuncts denoting the same feature, provided there is such a pre-adjunct.

As an opposition to kistjes sigaren [boxes (of) cigars] we cannot use sigarenkistjes [cigar-boxes (one word)]; the latter is not a construction, but a word in Dutch and therefore sigaren-is not an adjunct to -kisijes. Without such a comparison, however, we remark that in the construction the word sigaren can be used with all kinds of adjuncts it can get when it is used freely: kistjes kleine sigaren [boxes (of) small cigars] or kistjes sigaren uit Favanna (.... from Havanna) etc.

\section{Contchision I:}

From these possibilities it is evident that sigaren in kistjes sigaren refers to much the same thing as is denoted by this word in free use.

We are more fortunate with van hout [(made) of wood], which may be compared with the pre-adjunct houten (wooden). We can specify van hout, e.g. wan wit houi (of white wood); the corresponding preadjunct is withouten [white-wooden (one word)]. Also van hout can be specified to van zulk hout (of such wood) or to van hout met kweisten (.... with knots) or wan hout dat geimporteerd is (.... that has been imported), with which correspond no or only highly suspicious pre-adjuncts (geïmporteerd-houten kistjes?) [imported-wooden (one word!) boxes?)]. 


\section{Conclusion $I I$ :}

In the construction van hout the word hout can to a high degree be specified as the word hout in free use; so it denotes there a thing, considered with much the same independence; from withouten and the impossibilities it is clear that some quite normal features of the thing denoted in the word hout, cannot at all or not separately be denoted with houten; from this we draw the conclusion that in the latter word the thing wood is not considered independently.

Comparable to aaar [(over) there] we think the pre-adjunct die (those or this), referring directly to a thing (so not with mediate reference via a word, like in: Once upon a time there was a king and this king had a beautiful daughter). We point out that daar refers to a thing denotable in op die plaats (in that place), which may be under the table or on the chair etc. Now we can specify die kistjes daar beneden (those boxes there below) or die kistjes daar op de stoel (those boxes there on the chair). Such a specification is impossible with die (those or ths): Die op de stoei kisties (Those on the chair boxes) is impossible, while in die kistjes op de stoel (those boxes on the chair) not the word die, but the construction die kistjes is specified.

\section{Conclusion III:}

From the possible specifications of die kistjes daar we conclude that a speaker thinks in daar the same thing as when he uses that word freely, while from the impossible construction with die it is clear that a speaker does not think of a place explicit

With kistjes die besteld waren [boxes (that had been) ordered] may be compared bestelde kistjes (ordered boxes). In the former construction besield is specified by waren and it may be specified by other forms of the verb zijn (to be): kistjes die vandaag besteld zijn (..... that have been ordered to-day) or die op ro juli a.s. besteld zullen zijn $(\ldots$ that will have been ordered on the tenth of July next) or die op ro juli j.l. besteld zouden zijn (.... that would have been ordered on the tenth of July last). For what we try to demonstrate the possibility of kistjes die ik besteld heb [boxes (that) I (have) ordered] is also important. The corresponding pre-adjunct is always only besteld: de (vandaag-gisteren-op ro juli a.s. - op ro juli j.l. - door mij) bestelde kistjes [the (to-day - yesterday - on the tenth of July next or last - by me) ordered boxes]. 
If we add the difference between kistjes die niet besteid waren and niet-iestelde kistjes [boxes that have not been ordered and not-ordered (one word!) boxes], we may conclude from all these comparisons:

Conclasion IV:

In besteld in the post-adjunct the speaker thinks the same independent process as denoted by bestellen per se; in the pre-adjunct he does not.

To kistjes wankelen (boxes totter) we oppose (naar mijn mening) wankelende kistjes [(in my opinion) tottering boxes]. The former construction may be varied as follows: kistjes wankelden - zullen wankelen - zouden wankelen (boxes tottered - will or would totter) and especially again. if instead of reankelen we take the transitive verb breken (to h.eak), de kisljes worden door mij gebroken (the boxes are broken by me); in opposition to all these we only have: (naar mijn mening) wankelende kistjes (c.q. door mijn toedoen brekende of gebroken kistjes) [(in my spinion) tottering boxes, (c.q. breaking or broken bores)]. Another possibility is .... hebben (hadden) gewankeld [have (had) tottered], to which the only oppusition is wankelende kistjes and noi the merely theoreticil gewankeld hebber,de kistjes (having tottered boxes!). Finally there is de kisijwi soranbien niet [.... (do) not totter], to which the opposition is de niet-wankelende kistjes [the not-tottering (one word) boxes]. From all these facts we infer:

\section{Concusion $V$ :}

The thing meant by the finite verb wankelen in the post-adjunct is the same as denoted in the infinitive, but the one in the pre-adjunct is not.

We combine conciusions I up to and including $\mathrm{V}$ to a

Resultrng Conclusion A:

Pro-adjuncts denote things thought as dependent, that is as adhere $t$ to the thing denoted by the noun, whereas in post-cidjuncts things are denoted, which to a certain degree are regarded as independent. In other words: a construction pre-adjunct i- noun refers to something regarded as a unity; a construction noun + post-adjunct to something regarded as a whole. The difference between a unity and a whole we define in the scholastic way: Unum est id quod est indivisum in se; totum est omne id quod unum est et existit in partibus. 
So pre-adjuncts denote distinguishable moments of a unity and post-adjuncts separable parts of a whole.

A confirmation of our resulting conclusion may be found in a conditional possibility of use of all pre-adjuncts, which post-adjuncts have not. A thing which is more properly denoted with a noun, may also be denoted with a construction article + pre-adjunct. E.g. Ze hadden een roou' en een geel kopje. Het rode was mooier, maar het gele was minder breekbaar [They had a red teacup and a yellow one. The red (one) was more beautiful, but the yellow (one) less fragile]. Cf. also: $D e$ drie (b.v. jongens) besloten elkaar te helpen [The three (e.g. boys) decided to help each other]; Vier (b.v. kopjes) waren er beschadigd [Four (e.g. cups) were damaged]; Mijne (b.v. schoenen) hebben rubber zolen [My (!) (e.g. shoes) have rubber soles].

Post-adjuncts do not possess this possibility. E.g. de kopjes hier $\neq$ de hier (the cups over here $\neq$ the over here); een klontje suiker $\neq$ een suiker (a lump of sugar $\neq$ a sugar); de oom uit Amerika $\neq$ de uit Amerika (the uncle from America $\neq$ the from America).

However, this way of use of pre-adjuncts is conditional: the hearer must know in some way to what thing the pre-adjunct refers, e.g. from the situation or from a preceding sentence. This proves that the characteristic mentioned in the pre-adjunct is considered not as separated, but as distinguished only from the thing of which it is a characteristic.

Note: It is perhaps superfluous to point out that beside the abovementioned syntactic features, also certain lexical, morfological and paramorfological peculiarities (dat kistje versus aie kist; hout-en; besteld-e) ["boxlet" and box with different gender shown in the demonstrative pronoun; wood-en; an inflexional -e in the pre-adjunct besteld, the use of which depends on number, gender or other features of the noun with which it is constructed] are features that point in the same direction as our resulting conclusion $A$.

In the preceding pages we mentioned features of post-adjuncts (or of central elements of post-adjuncts) which they also had in free use, or which the opposing pre-adjunct had not or not in the same way. This led us to the conclusion that in those adjuncts a thing was denoted which to a certain degree was regarded as independent. In what follows we shall see that post-adjuncts (or central elements in them) 
lack certain features they do have in free use. This will lead us to further conclusions.

For instance: To zelfs sigaren (even cigars) there is no opposition kistjes zelfs sigaren. If one is astonished at the cigars, one says zelfs kistjes sigaren [even boxes (of) cigars, with a high pitch on cigars]. From this it is clear that the astonishment does not refer to the cigars, but to the cigars in the boxes; in other words the cigars are regarded as "contents of the boxes". Impossible is also kistjes de sigaren (boxes the cigars); the possibility of identification is lost through their being thought as contents.

The fact that neither adjuncts of definite nor of indefinite number can accompany sigaren in kistjes sigaren is caused by a totally different principle, to which we shall return later. The impossibility of kisten die sigaren daar [boxes (of) those cigars there] as the opposition to die sigaren daar (those cigars there) does point in the same direction: as contents of the boxes the cigars are already specified locally.

\section{Conclusion VI is then:}

In kistjes sigaren the thing meant by sigaren is regarded as contents of the boxes.

To ook hout (also wood) there is no opposition kistjes van ook hout (boxes of also wood). If one wants to stress that wood is included, one says kistjes ook van hout or ook kistjes van hout (boxes also of wood or also boxes of wood, with a high pitch on wood). From this it is apparent that the thing meant by hout is considered as the material of the boxes.

A second difference is that hout in van hout cannot be used as subject to a predicate, at least not with the same meaning [in e.g. van dat hout wordt hier niet verkocht (of this wood is not sold here) the meaning is: this kind of wood]. The reason is that the thing meant by it functions as material of the boxes. So we are justified to draw our

\section{Conclusion VII:}

In kistjes van hout the thing meant by hout is regarded as material of the boxes.

In order to be more easily understood we change our text a little and add a little piece of context. We use .... de stoel. De kistjes daarop $\ldots . . . .(\ldots$.$) the chair. The boxes thereon . . .$.$) . In$ 
daarop we refer to something that could also be denoted in $o p$ die stoel (on that chair). So in the construction de kistjes daarop the deictic element for chair is not the usual demonstrative pronoun die (this), but the deictic adverb daar- (there-). From this fact we draw

\section{Conclusion VIII:}

The thing meant by daar $(-)$ is regarded as the place of the boxes.

Before dealing with kistjes die besteld zijn [boxes (that have been) ordered], we point out that we shall not speak of the continuative relative clause here (which is, as Mrs. G. F. Bos states in a ms. not yet published, internally predicating). We did not deal with predicating use of the other post-adjuncts either, though it is equally possible there. Moreover, in the case of internally predicating use of pre-adjuncts, the opposition of place between pre- and post-adjuncts mostly disappears (kistjes, houten, stonden op de tafel) (boxes, wooden, were on the table), so by dealing with internally predicating use of adjuncts we should cloud our issue.

Therefore, in order to simplify the problem of the restrictive relative clause as a post-adjunct, we remark, that features denoted in pre-adjuncts as well as in post-adjuncts can be denoted in such a clause. Cf. rode kistjes (red boxes) and kistjes die rood zijn (boxes that are red) with kistjes van hout (boxes of wood) and kistjes die van hout zijn (boxes that are of wood) etc.

All we said before conclusion VII about hout in the construction kistjes van hout, also holds for that word in the construction kistjes die van hout zijn. So mutatis mutandis we can draw

\section{Conclusion $I X$ :}

The thing denoted in the predicate or the predicative noun of a restrictive relative clause is the same as that meant by the corresponding word in free use, but it is not regarded as the thing as such.

Note: The presence of a relative pronoun [c.q. relative (pronominal) adverb] anc of a finite verb will be discussed later.

We pointed out already that the thing meant in wankelen (totter) in the construction kistjes wankelen (boxes totter) is much the same as that meant in the infinitive. From the obligatory use of a finite verb, congruent in "person" (speaker, hearer etc.) and number with its subject, we infer: 


\section{Conclusion $X$ :}

The thing denoted in a finite verb is the same as that meant in the infinitive, but it is not considered as such, but as the predicate of an opinion about the thing meant in the subject.

From the resulting conclusion $A$, combined with conclusions VI up to and including $\mathrm{X}$ we infer a

\section{Resulting Conclusion B:}

The things meant by (the central element of) post-adjuncts are the same as denoted in the corresponding words in free use; however, they are not regarded as such, but in some function of the thing denoted in the noun: e.g. as contents, material or place of or as predicate of an opinion about that thing.

This way of regarding a thing is the way in which we regard the second correlate in a relation. Here we see another category of logic existing in language. We quote L. S. Stebbing, A. Modern Introduction to Logic, p. 166: "Any object of which we can think possesses characteristics that enable us to distinguish it from other objects. These characteristics are of two kinds: qualities and relations". And p. 167-8: "Every relation has a sense, i.e. the direction in which it goes. For example, loves goes from the lover to the loved, father of goes from the male parent to the child. The term from which the relation goes is the referent, the term to which the relation goes is the relatum. If A loves B, A is referent, B is relatum". Making gratefully use of this terminology, we can state: In a construction noun + postadjunct, the noun denotes the referent and the post-adjunct the relatum of a relation. Summa summarum: Post-adjuncts are relatumadjuncts.

In order to avoid being misunderstood we may remark: The semantic value of a construction pre-adjunct + noun (e.g. red boxes) is not equal to the sum total of the two meanings; the construction also implies that the two words are related. However, this is a relation between words or meanings of words. What exists between the things meant, however, is no relation: that would be a relation between a thing and a quality of that thing. (See L. S. Stebbing, o.c. p. 166.) In a construction noun + post-adjunct not only the immediate constituents are related, but also the things meant by them.

Before investigating the semantic order of these adjuncts, we shall 
deal with another peculiarity of the construction een kistje sigaren [a box (of) cigars]. This construction can be specified to ruim or royaal (over) or bijna (almost) een kistje sigaren; all these words are normally specifications of number-words (ruim dertien, bijna een dozijn) (over thirteen, almost a dozen). To this we add the impossibility already noted of een kistje 100 sigaren; thus we draw the conclusion: In the construction een kistje sigaren it is possible not only to consider the cigars in their relation of contents of the boxes, but also the boxes in their relation of quantity of the cigars. So the direction of the relation is indifferent. In the construction itself it is not denoted which word denotes the first and which one the second correlate of the relation; sometimes this can be gathered from the sentence: zij rookten kisten sigaren (they smoked boxes of cigars), where sigaren is the head, but er staan kisten wijn op tafel (there are boxes of wine on the table), where from the rection of number we gather that kisten is meant as the head.

Knowing now what the post-adjuncts have in common (i.e. that they are relatum-adjuncts) we shall investigate the differences to find grounds for a semantic order.

We begin with kistjes sigaren and call to mind the fact that the boxes there are always cigar-boxes [otherwise they are kistjes met sigaren (boxes with cigars)]; that means that they are to a high degree defined in shape, material and even purpose of existence by their relation to cigars. If we oppose to them kistjes geld (boxes of money), which are always money-boxes, there is a possibility of change in shape and material and anyhow the existence of the boxes as cigar-boxes is finished.

In kistjes van hout opposed to kistjes van ijzer (made of iron) only the material changes; though not the feature or combination of features by which things are boxes. So the change here is not so great as with kistjes sigaren en kistjes geld; in other words: the relation meant in kistjes sigaren is more inherent to the boxes than the one meant in kistjes van hout.

To the same class as kistjes sigaren belong the types: een klontje suiker (a lump of sugar), het eiland Capri (the isle of Capri), het planErftemeyer [the plan (made by) Erftemeyer], het woord "mooi" (the word "beautiful"), het begrip paard (the concept horse), Paus Pius (Pope Pius) and de herbergier Doodewaard (the inn-keeper Doodewaard) 
To the same class as van hout belong other constructions with a preposition: kistjes van Piet [.... of Peter's], uit Duitsland (from Germany), met een barst (with a crack). As we have here relations between things without any other moment of thought, I should like to call them objective relations. A further account of this term we shall give below. However, we have to make the remark that not all post-adjuncts with a preposition are equally inherent; it is clear that the relation meant in kistjes van hout is more inherent than the one meant in kistjes van Piet, but this will hardly ever be shown: a construction as kistjes van hout van Piet has hardly any frequency of use.

Opposed to de kistjes daar (the boxes over there) are de kistjes hier [..... (over) here]; the change no longer regards the boxes themselves, but something of the boxes, i.e. their place. So the extent of the change is smaller and the relation less inherent.

As the relation thought in de kistjes hier is relative to the same type of relation of other boxes (i.e. a place closer to the speaker), we want to speak here of a relative relation, in opposition to the objective relation mentioned above.

To the same class belong adjuncts denoting a time relative to the time of the context (.... gisteren; nu; morgen etc.) (yesterday; now; tomorrow). A clear difference between objective and relative relations is seen in 1. Hij eet altijd liever brood van gisteren (He always prefers to eat bread of yesterday). A sentence as 2 . Hij eet altijd liever brood gisteren (.... bread yesterday) is impossible in Dutch. The cause of the difference is: in sentence 1 . the thing meant by gisteren is a day preceding a given day (so an objectivated yesterday), but in 2 . the day preceding to the present of the context (a relative yesterday). As by gisteren in 2. a definite time is denoted, the thing meant by brond is accordingly identified. The construction brood gisteren as a part of the sentence is consequently only possible when preceded by het or dat (the or that).

In order to demonstrate the typical teature of meaning of the restrictive relative clause, we oppose kistjes van hout to kistjes die van hout zijn [boxes (made) of wood to boxes tiat are (made) of wood]. Here the same objective relation is considered, but in the second construction something more as well. This is apparent from the fact that a construction deze kistjes van hout is quite normal, whereas deze kistjes die van hout zijn is unusual, if not impossible. Perhaps it 
may be used with contrasting stress on deze. The cause is already indicated in the usual Dutch name distinctive relative clause. Apparently the speaker appreciates the relation between boxes and wood as so importan! that he does not only specify, but also classify the boxes on the basis of the presence or absence of that relation: de kistjes die van hout zijn are deze kistjes (these boxes) and de kistjes die niet van hout zijn are die kistjes (those boxes). Or put differently: kistjes die van hout zijn are zulke kistjes (such boxes) and kistjes die niet van hout zijn are andere kistjes (other boxes). In both cases we have a relation appreciated by the speaker, so a subjective relation. That the latter is less inherent than a relative relation needs no demonstration.

In this type of post-adjunct we find a relative pronoun and a finite verb. We shall try to explain this presence, i.e. try to show the functional burden of these two elements. To denote the subjective moment in this relation the predicating construction subject + finite verb is apparently necessary, for this construction is subjective as we shall see.

The relative pronoun is necessary when the thing meant in the antecedent is thought as the agent of the process denoted in the predicate: One has to say kistjes die wankelen (gooi $i k$ weg) [boxes that totter (I throw away)], because by omitting die, one gets a predicating construction, whereas the speaker does not want to predicate. So the function of die is to show that not a predicating construction is meant.

Note I: In German a finite verb is not used in this construction if the verb is a semi-morpheme: Den Mann der das gesagt (hat), möchte ich mal sehen [The man that (has) said this, I should like to see] or Der Mann der gestern hier gewesen (ist), ist sein Onkel [The man that (has) been here yesterday, is his uncle].

Note 2: When the subordinate clause begins with a relative pronominal adverb, in talking-style the function of die can be taken over by the conjunction dat (that): De man waarmee dat ik jou gezien heb.... (With apologies: The man whom-with that I have seen you).

Note 3: In such cases and also when the thing meant in the antecedent is not thought as the agent of the process mentioned, the English often use no relative pronoun: The girl I saw ...; The girl we were talking of .....

Finally we discuss the construction subject + finite verb or equiva- 
lent. The speaker denotes here not only a relation between a thing and a process, but also his belief in the existence of the relation in reality. This special kind of subjective relation is called a predicating relation; it goes without saying that this relation is less inherent to the thing meant in the nour than the normal subjective relation.

We are able now to summarize the relation of the order of succession of post-adjuncts and their meaning in a simple thesis: The more inherent the relation thought, the closer the adjunct stands to the noun. The conciseness of this thesis be the excuse for its inexactitude!

As a summary of the things found up to now we present them again in the form of a talle :

Order of post-adjuncts to a noun

\begin{tabular}{|c|c|c|c|c|}
\hline \multicolumn{4}{|c|}{ non-predicating } & predicating \\
\hline \multicolumn{3}{|c|}{ non-subjective } & \multirow[t]{3}{*}{ subjective } & \multirow[b]{4}{*}{$\begin{array}{l}\text { 5th place } \\
\text { finite verbs } \\
\text { or equivalents } \\
\text { e.g. wankelen }\end{array}$} \\
\hline \multicolumn{2}{|c|}{ non-relative } & \multirow[t]{2}{*}{ relative } & & \\
\hline non-objective & objective & & & \\
\hline $\begin{array}{c}\text { 1st place } \\
\text { substantives }\end{array}$ & $\begin{array}{l}\text { 2nd place } \\
\text { constructions } \\
\text { with a prepo- } \\
\text { sition } \\
\text { e.g. van hout }\end{array}$ & $\begin{array}{c}3 \mathrm{~d} \text { place } \\
\text { adverbs of } \\
\text { place/time } \\
\text { e.g. daar }\end{array}$ & $\begin{array}{c}\text { 4th place } \\
\text { restrictive re- } \\
\text { lative clause } \\
\text { e.g. die besteld } \\
\text { zijn }\end{array}$ & \\
\hline
\end{tabular}

We will end with a few notes:

1. A. W. de Groot in a ms. not yet published rightly points out that the place of an adjunct respective to that of other adjuncts is not an immediate, but a mediate feature. Hereby is meant: If a speaker wants to specify a thing denotable in kistjes by features denotable in sigaren en van hout, normally sigaren, owing to its more inherent meaning, is not an adjunct to kistjes van hout, but van hout, owing to its less inherent meaning, is an adjunct to kistjes sigaren. So the second place of van hout is caused by the presence of a more inherent adjunct.

2. We point out that the order found here is the reverse of the order of qualitative pre-adjuncts to nouns, as shown in our: "Kategorieën 
van voorgeplaatste bepalingen bij substantieven" (see Introduction).

3. With this result, together with the above-mentioned article, the investigation of the word-order in the most normal type of assertive sentences (i.e. the assertive sentence beginning with the subject), is concluded. However, this only refers to what we would call the minimal assertive sentence; about the order of adjuncts to verbs (or to the construction subject + finite verb) a great deal is stiii awaiting investigation.

Utrecht

H. Roose 